\title{
Magnetic excursions recorded in the Middle to Upper Pleistocene loess/palaeosol sequence Wels-Aschet [Austria]
}

\author{
Robert Scholger, Birgit Terhorst
}

How to cite:

Scholger, R., Terhorst, B. (2013): Magnetic excursions recorded in the Middle to Upper Pleistocene loess/palaeosol sequence Wels-Aschet (Austria). - E\&G Quaternary Science Journal, 62 (1): 14-21. DOI: 10.3285/eg.62.1.02

\begin{abstract}
We present the palaeomagnetic examination of the Middle to Upper Pleistocene loess/palaeosol sequence in the former pit 'Würzburger' located in Aschet near Wels. Five strongly developed palaeosols, respectively pedocomplexes alternate with interposing loess loam. By means of excavation access was gained to a profile with a thickness of $12 \mathrm{~m}$. Altogether, 587 orientated samples were taken for the magnetostratigraphic analysis at the Paleomagnetic laboratory of the Montanuniversität Leoben, ensuring a nearcomplete sampling. The samples were demagnetised by means of alternating field as well as thermal demagnetisation. The magnetic parameters show a sequence of sections with strong magnetite formation in the soil, which can be assigned to the relatively warm climate of interglacial periods. The majority of samples showed characteristic remanence directions within the range of the normal global magnetic field of the Pleistocene. Some sections showed strongly deviating remanence directions, indicating excursions of the global magnetic field. The excursions observed in the Wels-Aschet profile are assigned to the time interval of $570 \mathrm{ka}$ (Emperor-Big Lost-Calabrian Ridge) until $110 \mathrm{ka}$ (Blake) due to palaeopedological-stratigraphical considerations. The Brunhes/ Matuyama-Boundary (776 ka) was not reached.
\end{abstract}

Magnetische Exkursionen in der Mittel- bis Oberpleistozänen Löss-/Paläoboden-Sequenz Wels-Aschet

Kurzfassung:

Die vorliegende Arbeit stellt die paläomagnetische Bearbeitung der Mittel- bis Oberpleistozänen Löss-/Paläoboden-Sequenz im Areal der ehemaligen Ziegelei Würzburger in Aschet bei Wels vor. Fünf intensiv entwickelte Paläoböden, bzw. Pedokomplexe wechseln mit dazwischen geschalteten Lößlehmlagen ab. Im Rahmen einer Aufbaggerung konnte ein Profil mit einer Mächtigkeit von über 12 m erschlossen werden. Für die magnetostratigraphischen Laboruntersuchungen im Paläomagnetiklabor der Montanuniversität Leoben wurden insgesamt 587 orientierte Proben entnommen, so dass eine beinahe lückenlose Beprobung vorliegt. Die Proben wurden mit magnetischen Wechselfeldern sowie thermisch abmagnetisiert. Zur Bestimmung der magnetischen Trägerminerale in den Sedimenten wurden Curiepunkt-Bestimmungen durchgeführt, die eine Hauptträgerphase mit einem Curie-Punkt bei ca. $580^{\circ} \mathrm{C}$ (Magnetit), sowie untergeordnete Anteile von Hämatit mit $670^{\circ} \mathrm{C}$ Curie-Punkt ergaben. Die magnetischen Parameter zeigen eine Folge von Bereichen mit intensiver Magnetitbildung in den Paläoböden, die dem relativ wärmeren Klima von Interglazialen zugeordnet werden können. Die Mehrzahl der Proben zeigen charakteristische Remanenzrichtungen im Bereich des normalen pleistozänen Erdmagnetfeldes. In einigen Profilabschnitten traten stark abweichende Remanenzrichtungen auf, die auf Exkursionen des Erdmagnetfeldes hinweisen. Die beobachteten Exkursionen im Profil Wels-Aschet werden aufgrund paläopedologischerpedostratigraphischer Ergebnisse in das Zeitintervall von 570 ka (Emperor - Big Lost - Calabrian Ridge) bis 110 ka (Blake) gestellt. Die Brunhes/Matuyama-Grenze (776 ka) wurde nicht erreicht.

Keywords: $\quad$ Pleistocene, loess, palaeosol, magnetic excursion, chronostratigraphy, rock magnetic properties, Upper Austria

Address of author: $\quad$ R. Scholger, Montanuniversität Leoben, Paleomagnetic Laboratory Gams, Chair of Applied Geophysics, Peter-Tunner-Str. 25,
A-8700 Leoben, Austria, E-mail: scholger@unileoben.ac.at; B. Terhorst, University of Würzburg, Institute of Geography and GeolA-8700 Leoben, Austria, E-mail: scholger@unileoben.ac.at; B. Terhorst, University of Würzbur
ogy, Am Hubland, D-97074 Würzburg, Germany. E-Mail: birgit.terhorst@uni-wuerzburg.de

\section{Introduction}

\subsection{Stratigraphic framework of the study area}

The Older Deckenschotter/Günz terraces of the Traun-EnnsPlatte are classified according to stratigraphic considerations as belonging to the seventh-last glacial period. In this context VAN Husen (2000) and VAN Husen \& Reitner (2011) proposed a chronostratigraphic framework for the glacial deposits and processes during the Middle Pleistocene of the Eastern Alps. In this study we assume that the four classic glacial periods are to be assigned to the Brunhes-Chron.
VAn HusEn (2000) assumes that Günz is to be correlated with MIS16 and Mindel with MIS12. Furthermore, the author places the Riß-Glacial in MIS 6 and the Würmian Glacial in MIS 2. On the basis of cover layer analyses in the Linz/Wels area, Terhorst (2007) and Terhorst et al. (2011, 2012) arrive at similar results. The authors also correlated Günz with MIS16 and Mindel with MIS12. Earlier investigations in the cover layers of fluvioglacial terraces in the Linz/Wels area clearly show that too many interglacial soils occur to support the classic conceptions according to PENCK \& BRÜCKNER (1909) (Kohl \& Krenmayr 1997, Stremme et al. 1991). 


\subsection{Palaeomagnetic investigations of loess/palaeosol sequences}

Climate change has an impact on weathering and sedimentation processes which affect the magnetic minerals within rocks (DEKKERs 1997). Therefore magnetic parameters such as magnetic susceptibility are sensitive indicators for climate dependant variations of the type, grain size and concentration of magnetic minerals in sediments (THOUVENy et al 1994, Verosub \& RoBERTs 1995). The magnetic susceptibility of rocks depends on the concentration and grain size of the magnetic mineral phases, which are part of the rock composition. In general, magnetite has the highest importance due to its high mineral specific susceptibility, and magnetic susceptibility can be used as a proxy for the magnetite content of rocks (THOMPSON \& OLDFIELD 1986).

Several extensive investigations of European and Asian loess profiles document that palaeosols mainly contain finely grained magnetite as carrier mineral of the magnetic properties, while the magnetic components of loess samples are characterised by larger single-domain and multidomain grain sizes (Evans \& Heller 2003). Since the magnetic susceptibility of SP-magnetite is significantly higher, it is possible to use the temporal variation of these parameters as an indicator for the intensity of soil formation (HELLER \& LIU 1984). Model hypotheses assume that changing redox conditions in the soil during the weathering of ferrous minerals lead to the release of iron and the regeneration of ferrihydrite. At the end of a reaction chain, SP-magnetite or maghaemite regenerate in the soil under oxidising conditions (MAHER 1998). CHEN et al. (2005) refer to the importance of the organic content in connection with the activity of ironreducing bacteria.

To date only few palaeomagnetic results of loess/palaeosol sequences in Austria are available. Earlier investigations of the clay pit of the brickyard Würzburger in Aschet/ Wels are described in Fink et al. (1976). For the first attempt at a palaeomagnetic dating of these sediments, samples were taken from the cover layer above the older sheet gravels every 20 to $40 \mathrm{~cm}$, which all showed a positive inclination and a declination of approximately zero. Sedimentary processes at the base of the cover layers are given as a possible reason for the absence of the expected polarity reversal (BrunhesMatuyama Boundary) as well as the strong variation in declination values in the lowest part of the profile (FINK et al. 1976). The profile Wels-Aschet was dug up and documented anew in 2003 by a working group headed by Prof. Dr. Dirk Van Husen (SCHOlger \& Terhorst 2011).

\section{Palaeopedological setting of the Wels-Aschet sequence}

Older studies on the loam pit of Pichler brickyard in WelsAschet are available by KoHL \& Krenmayr (1997), KoHL (2000) and Stremme et al. (1991). A detailed description and sedimentological analyses can be found in TERHORST et al. (2011, 2012).

Altogether, the loess/palaeosol sequence of the studied profile reaches a thickness of $12.5 \mathrm{~m}$. It is mostly decalcified while gravel deposits of the Older Deckenschotter show high $\mathrm{CaCO}_{3}$ contents. The sequence contains five palaeosols of interglacial intensity, while strong weathering of the lowermost palaeosol is especially conspicuous. The basal sections of the profile display an intensely reddish-brown weathered horizon (AS 2) with dark red clay cutans in the gravels of the Older Deckenschotter (AS 1). Above the palaeosol, which represents at least one interglacial period, redeposited, gravel-bearing layers are deposited, which were later covered by a $3.5 \mathrm{~m}$ thick loess loam (AS $4 \mathrm{a}-4 \mathrm{e}$ ), which intercalates two Cryosols. On top of the loess loam (AS 4a) a palaeosol developed in form of a dark yellowish brown Btg horizon of interglacial intensity (AS 5).

A further, thin and unstructured layer of loess loam (AS 6) overlies palaeosol AS 5. Above this loam a multiply layered pedocomplex is developed (AS 8a to 7c). The basal, $3^{\text {rd }}$ palaeosol (AS 7b, 7c) contains distinct reddish brown clay cutans. This pedocomplex can be clearly distinguished from the overlying $2^{\text {nd }}$ Btg horizon (AS 7a) by an erosional unconformity and a change in grain sizes (TERHORST et al. 2011). Two stagnic horizons (AS 8 and $8 \mathrm{a}$ ) are superimposed on the described pedocomplex. On top of this pedocomplex, a loess loam with $1 \mathrm{~m}$ thickness is present, which is not subdivided any further (AS 9). Within the loess loam an interglacial soil is developed, which is represented by an intense, $1.10 \mathrm{~m}$ thick, dark brown Bt horizon (AS 10). This palaeosol horizon is correlative with the MIS 5e (Preusser \& FIEBIG 2009, TERHORST et al. 2011). A Würmian sequence, which in comparison to other profiles is reduced and poorly weathered, covers the Eemian palaeosol (AS 11 to AS 16).

\section{Methods}

By means of two excavations $(2001,2003)$ access was gained to a profile of a thickness of more than $12 \mathrm{~m}$. Samples for the palaeomagnetic laboratory analysis were collected using plastic cubes (edge length $2 \mathrm{~cm}$ ) which were pushed into the sediment either by hand or hammer along a guide rail. The orientation of the samples was measured according to routine palaeomagnetic proceedings. 162 (2001) and 425 (2003) samples were taken for the magnetostratigraphic laboratory analyses. The undetermined vertical distance between individual samples lies between 0 and $2 \mathrm{~cm}$, ensuring a nearcomplete sampling. The continuous in situ measuring of the magnetic volume susceptibility in the profile was performed with an Exploranium KT-9 Kappameter.

Magnetic volume susceptibility as well as natural remanent magnetisation were measured at the Paleomagnetic Laboratory of the Montanuniversität Leoben as reference values for further investigations. The remanence measurements were performed with a $2 \mathrm{G}$-Cryogenic-magnetometer with integrated alternating field demagnetisation, the susceptibility measurements on a Kappabridge Geofyzika KLY-2.

We first demagnetised the orientated samples with increasingly strong alternating magnetic fields (from 2 to 140 $\mathrm{mT}$ ), and subsequently thermally demagnetised selected samples at temperatures ranging from $200^{\circ}$ to $550^{\circ}$, the remaining NRM being measured after every step of the cleaning process. The demagnetisation behaviour indicates the magnetic carrier minerals and allows the separation of primary fossil magnetisation directions from secondary magnetisations created by magnetic overprints and weathering. 
To determine the magnetic carrier minerals in the sediments, we performed Curie point determinations and examined the magnetic saturation behaviour. Depending on the deposit and formation conditions of the sediments and soils, different significance to the various magnetic parameters connected to certain sedimentologic or climatic processes is assigned. For the present study we chose the parameter AF@ IRM according to LARRASOANA et al. (2003), which is regarded as an indicator for the haematite content within rocks. We first exposed the samples to a magnetic saturation at $0,9 \mathrm{~T}$ and subsequently demagnetised them in an alternating field at $100 \mathrm{mT}$. The remaining magnetisation is most likely due to haematite. At the same time we measured the anisotropy of the magnetic susceptibility (AMS), which determines the fabric of the magnetic minerals within the rock.

\section{Results \\ 4.1 Carrier minerals of the magnetic properties}

The results of the Curie point determination yielded a magnetic carrier phase with a Curie point of approximately $580^{\circ} \mathrm{C}$ (magnetite) as well as a subordinate haematite content with a Curie point of $670^{\circ} \mathrm{C}$. An increase in magnetic susceptibility between $280^{\circ} \mathrm{C}$ and $350^{\circ} \mathrm{C}$ most likely results from a transformation of iron sulphides or iron hydroxides into secondary magnetite or maghaemite during the heating process (GENDLER et al. 2006). The magnetic saturation indicates various magnetic minerals in the loess sediments and palaeosols of the Aschet profile. Samples from the palaeosols are characterised by a relatively low coercivity and reach magnetic saturation faster than the samples from loess horizons. The saturation behaviour of the samples indicates variations of low-and highly-coercive magnetic minerals in different concentrations. A highly coercive mineral (haematite) is present in low concentrations in all samples; the palaeo contain at least one additional low-coercive phase (magnetite) which developed during soil formation.

The measurements of the anisotropy of the magnetic susceptibility showed weakly anisotropic and in many cases isotropic magnetic fabric for all sections of the Aschet profile. The values for the magnetic fabric parameters, lineation (L) and foliation (F), lie below $2 \%$ for most samples (median value and standard deviation from 165 samples: $\mathrm{L}=1,014 \pm$ $0,018 ; F=1,018 \pm 0,017)$. We could not observe a preferred orientation of the Kmax direction, which would allow inferences as to palaeowind direction.

\subsection{Characteristic magnetisation directions}

The stepwise demagnetisation in an alternating field was performed in 6 to 15 stages ranging from 2 to $140 \mathrm{mT}$ (Figure 1). Considering the mineral magnetic results, the lower field range was examined in more detail to isolate those remanence vectors which reside in different phases of magnetite. In general we only observed a low impact of the highly coercive phases on demagnetisation behaviour. For the majority of samples the remanence could be demagnetised completely using alternating field demagnetisation. After demagnetisation in the alternating field, some samples showed remaining remanences which are due to highly coercive phases (e.g. haematite). We subsequently thermally demagnetised these samples at temperatures ranging from $200^{\circ} \mathrm{C}$ to $550^{\circ} \mathrm{C}$. We generally observed two magnetic phases which in most cases however yielded the same remanence direction (Figure 1 a,c).

We observed similar demagnetisation vectors in every loess and soil sample. The majority of samples showed characteristic remanence directions within the range of the normal recent or Pleistocene global magnetic field. In some sections of the profile strongly deviating remanence directions occurred (Figure $1 \mathrm{~b}, \mathrm{~d}$ ), which indicate excursions of the global magnetic field which also occurred repeatedly during the Pleistocene (LuND et al. 1998). However, we did not observe a complete polarity reversal of the magnetic field indicating the Brunhes-Matuyama Boundary.

Up to $90 \%$ of the natural remanent magnetisation (NRM) in the Bt horizon of the $1^{\text {st }}$ palaeosol (AS 10) as well as the subjacent loess loam (AS 9) were already demagnetised at low alternating fields. The subsequent thermal cleaning up to $550^{\circ} \mathrm{C}$ yielded further demagnetisation of the same directional component (Figure 1a). In the upper section of the $1^{\text {st }}$ palaeosol (AS 10) at the transition to the colluvial layer (AS 11), we observed strongly deviating remanence directions within an interval of approximately $20 \mathrm{~cm}$ in the profile $(1.90$ to $2.10 \mathrm{~m})$. Similar deviating magnetisation vectors occurred in the lower part of the loess loam AS 9 at a depth of 3.60 to $3.95 \mathrm{~m}$ as well as in the $2^{\text {nd }}$ and $3^{\text {rd }}$ palaeosols (Btg horizons, AS 7a, b) at a depth of 4.55 to $5.34 \mathrm{~m}$ (Figure 1b). The samples taken from AS 7 are characterised by a higher coercivity. The subsequent thermal cleaning resulted in a further loss of intensity at the temperature interval between $500^{\circ} \mathrm{C}$ and $550^{\circ} \mathrm{C}$, which indicates magnetite as the sole carrier mineral of the remanence. In the layers AS 4 the demagnetisations indicated an additional magnetic carrier mineral both in the loess loam as well as in the Cryosols. The alternating field demagnetisation showed that only approx. 50\% of the NRM were linked to lower coercive magnetic phases, most part of the remaining intensity could be removed during the first stages of thermal cleaning (Figure 1c). The samples taken from the $5^{\text {th }}$ palaeosol (Bt horizon, AS2) were similar to the $2^{\text {nd }}$ palaeosol in their demagnetisation behaviour. We were able to demagnetise the majority of NRM at alternating field strengths of up to $40 \mathrm{mT}$; Figure 1e). We mainly observed normal characteristic remanence directions for the whole lower part of the profile, between AS 1 and AS6, while deviating magnetisation vectors only occurred in a few samples taken from two depth sections (at approximately $9.5 \mathrm{~m}$ and $11.6 \mathrm{~m}$; Figure 1d).

\subsection{Variation of magnetic parameters in the profile}

Magnetic susceptibility, NRM intensity, saturation intensity and the parameter AF@IRM (LARRASOANA et al. 2003), which is used as an indicator for haematite, all showed significant variations in the profile (Figure 2). The continuous susceptibility profile recorded in situ during the sampling and the measurements of the samples show a strong link between magnetic susceptibility and lithologic conditions, with the palaeosols generally emerging as areas of increased susceptibility with concurrent large variation in susceptibility values. The susceptibility values for loess loam (approx. $150.10^{-6} \mathrm{SI}$ ) represent the magnetic background value of the sediment, while the values in the palaeosols are as much as 
a)

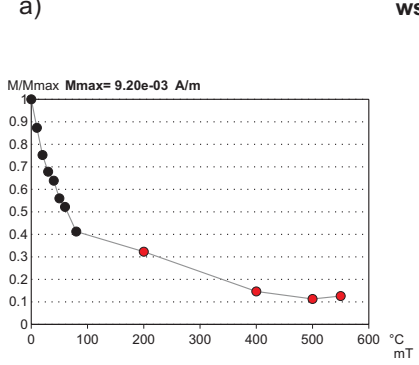

wsb373

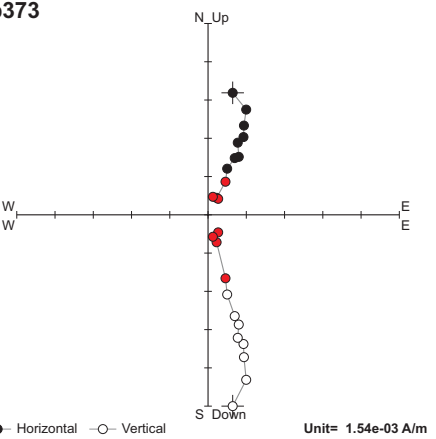

b)

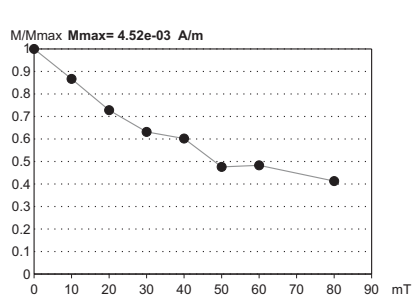

wsb263

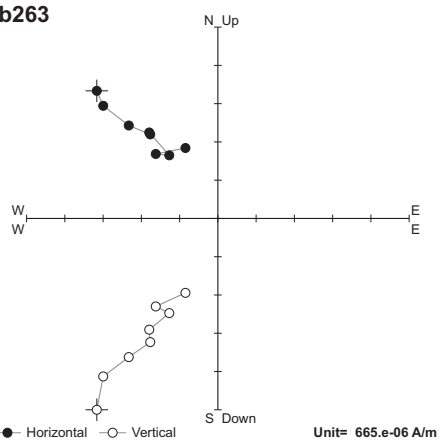

c)

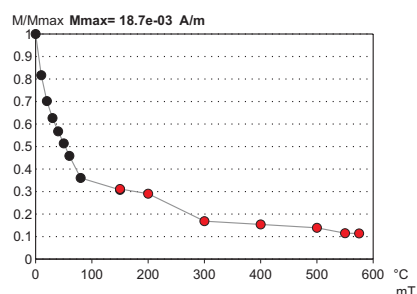

wsb083

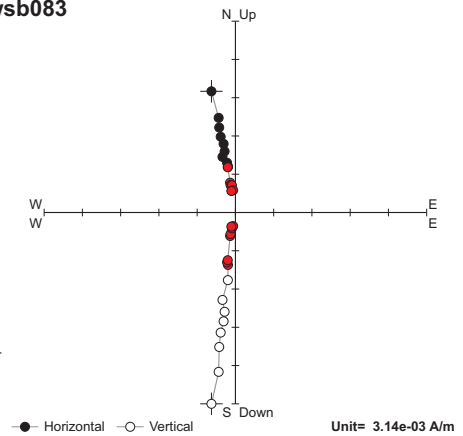

d)

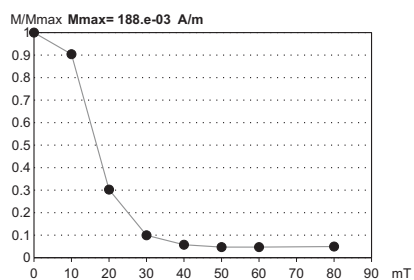

wsb023

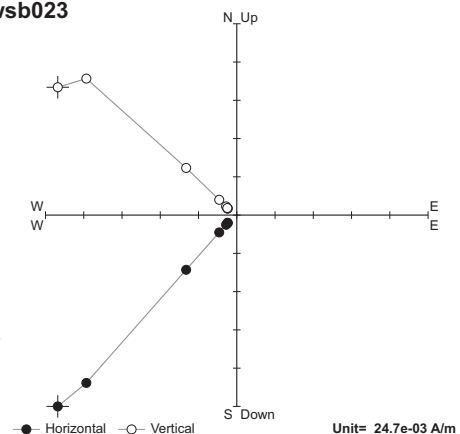

e)

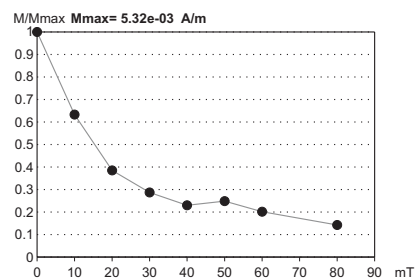

wsb003

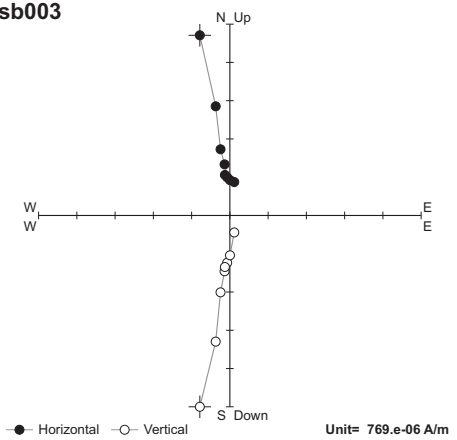

Figure 1: Vectorplots (horizontal und vertical projection) and intensity decay during alternating field-(black) and thermal (red) cleaning. (a) WSB373 of AS 10, (b) WSB 263 of AS 7, (c) WSB83 of AS 4e, (d) WSB23 of AS 2, (e) WSB 3 of AS 2. Alternating field demagnetisation in 6 to 15 steps in the range between 2 and $140 \mathrm{mT}$, successive thermal demagnetisation at temperatures between $200^{\circ} \mathrm{C}$ and $550^{\circ} \mathrm{C}(\mathrm{a}, \mathrm{c})$. In some sections of the profile strongly deviating remanence directions occurred $(b, d)$, which indicate excursions of the global magnetic field.

Abb. 1: Vektordiagramme und Intensitätsverhalten ausgewählter Proben bei der Abmagnetisierung. Horizontale und vertikale Projektion der Remanenzvektoren, sowie Intensitätsverlauf bei der Wechselfeld-(schwarz) und thermischen (rot) Reinigung. (a) WSB373 aus AS 10, (b) WSB 263 aus AS 7, (c) WSB83 aus AS 4e, (d) WSB23 aus AS 2, (e) WSB 3 aus AS 2. Abmagnetisierung im Wechselfeld in 6 bis 15 Schritten im Bereich zwischen 2 und $140 \mathrm{mT}$, nachfolgende thermische Abmagnetisierung bei Temperaturen von $200^{\circ} \mathrm{C}$ bis $550^{\circ} \mathrm{C}(\mathrm{a}, \mathrm{c})$. In einigen Bereichen des Profils traten stark abweichende Remanenzrichtungen auf die auf Exkursionen des Erdmagnetfeldes hinweisen $(b, d)$.

ten times higher due to magnetite-formation during pedogenesis. The intensity values of NRM and SIRM largely follow the same trend. Within the loess content of the profile, the haematite indicator AF@IRM shows similar behaviour to the other magnetic parameters. In contrast, we did not observe an increase of the AF@IRM values in the palaeosols. This confirms the hypothesis that the increased values of susceptibility, NRM and SIRM in the palaeosols are due to higher magnetite content.

The intensely weathered reddish palaeosol in the basal section of the profile (12 m-11 m) with the highest loam content in the profile represents at least one interglacial period and is slightly remoulded by cryoturbation (TERHORST 2007). In this section (AS 2) the susceptibility values are generally increased. A susceptibility and SIRM-maximum at $11.5 \mathrm{~m}$ and diverging remanence directions may indicate a shortterm excursion of the global magnetic field during soil formation or during a subsequent intense weathering period. In the superjacent loess loam complex with a thickness of $4 \mathrm{~m}$ (AS 4a-4e), the saturation magnetisation in particular indicates an increased magnetite content in the two Cryosols. At $9.5 \mathrm{~m}$ we observed an indication for a magnetic excursion. In the Btg horizon (AS 5) between $7.0 \mathrm{~m}$ and $6.6 \mathrm{~m}$, only individual samples show increased magnetic susceptibility, while the superjacent unsegmented loess loam layer AS 6 $(6.6 \mathrm{~m}-6.0 \mathrm{~m})$ is characterised by significantly increased susceptibility values. Within the multi-segmented pedocomplex AS $8 \mathrm{a}-7 \mathrm{c}$ (6 $\mathrm{m}$ to approx. $4.2 \mathrm{~m}$ ), with greyish iron-reduced areas along visibly developed root traces (TERHORST 2007), increased susceptibility and SIRM values also indicate partially intense magnetite formation, which can strongly vary locally depending on the availability of organic substances. In this pedocomplex we observed a magnetic excursion over a longer profile section, the magnetisation directions in the lower part (AS 7b) indicating a possible additional subdivision.

\section{Discussion}

Saturation intensity and magnetic susceptibility strongly vary within the profile, depending on the different lithologic horizons. Several horizons with strongly increased susceptibility values occur, which are due to higher concentrations 


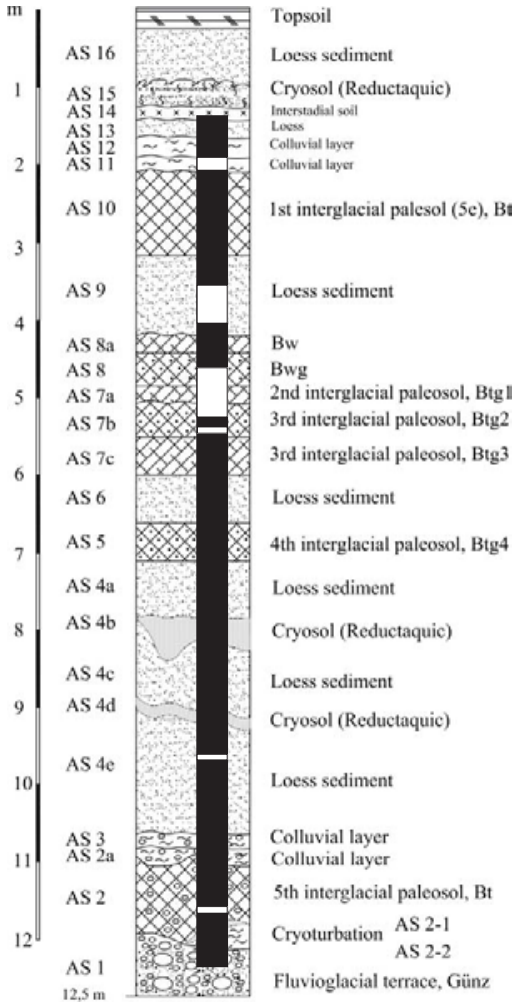
$12,5 \mathrm{~m}$
Fluvioglacial terrace, Günz

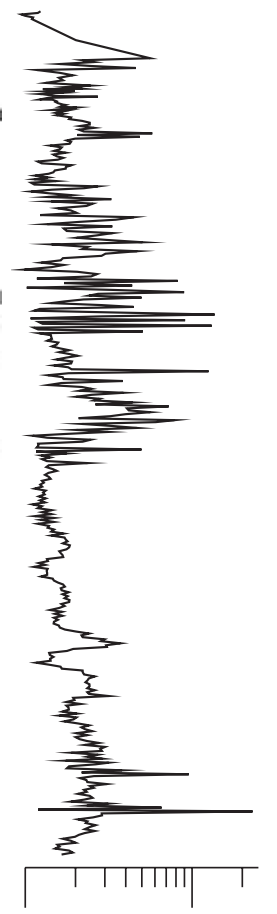

$100 \quad 1000$

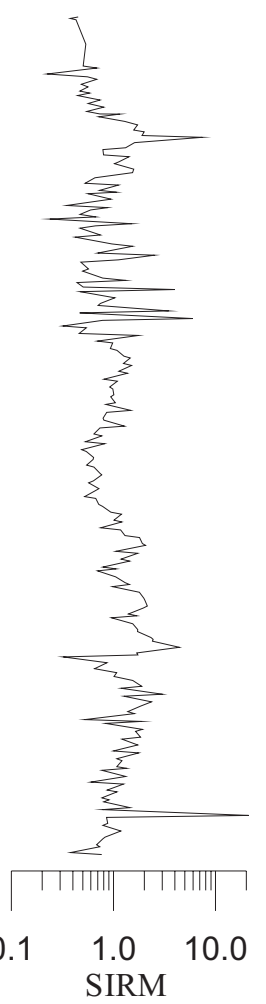

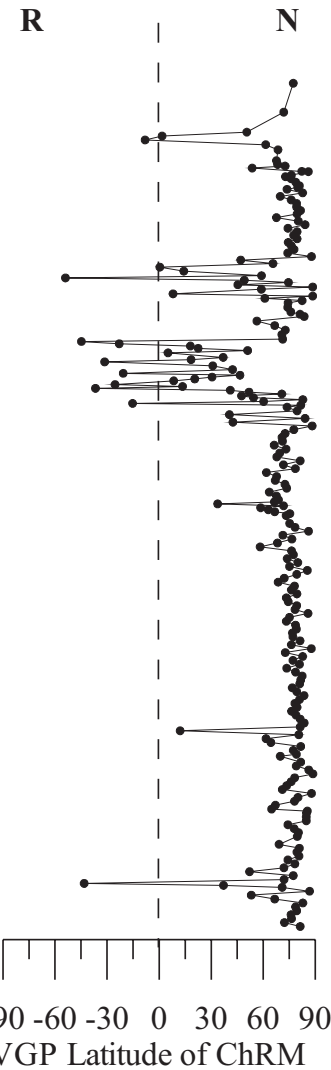

Figure 2: Variation of magnetic parameters in the profil Wels-Aschet. Magnetic suszeptibility (in 10-6 SI), intensity of saturation magnetisation (SIRM in $A / m$ ) and remaining remanence after successive alternating field demagnetisation (AFaIRM), VGP-Latitude calculated for the characteristic remanence component (ChRM). R, N: Inverse und Normal polarity. Geomagnetic Instabilty column for the profile Wels-Aschet (black: stable North direction, white: magnetic excursion).

Abb. 2: Magnetische Parameter der Proben aus dem Profil Wels-Aschet. Magnetische Suszeptibilität (in 10 ${ }^{-6}$ SI), Sättigungsmagnetisierung (SIRM in A/m) und Rest-Remanenz nach anschließender Abmagnetisierung im Wechselfeld (AF@IRM), VGP-Breitengrad der charakteristischen Remanenzkomponente (ChRM). R, N: Inverse und Normale Pollage. Geomagnetische Zuordnung im Profil (schwarz: stabile Nordrichtung, weiß: magnetische Exkursion).

of finely grained magnetite. Such horizons indicate climateregulated in situ soil formation during relatively warm climatic conditions. Investigations of loess profiles in China showed that palaeosol horizons are always characterised by high magnetic susceptibility and high saturation intensity (Heller \& Liu 1984, Hunt et al. 1995). Evans \& Heller (1994) proved that the magnetic characteristics are due to magnetite and pyrrhotite, which were created by pedogenesis. For attempting a chronostratigraphic classification, the magnetic susceptibility of profile sections is used as a climate indicator and compared to the oxygen isotope curve according to LisIECKI \& RAYMO (2005). For the chronostratigraphic classifications in the Aschet profile near Wels we used a current survey of internationally recognised observed excursions within the Brunhes-Chron (LAJ \& CHANNELL 2007, LANGEREIS et al. 1997, SINGER et al. 2008). Geomagnetic excursions represent short-term deviations from the normal global magnetic field, which can be observed as transregional phenomena (SINGER et al. 2008) and are therefore suitable for chronostratigraphic correlation. Magnetic excursions or polarity reversal within the assumed stable Brunhes-Chron were first discovered at Lavas located in the French
Massif Central (Laschamp, approx. $40 \mathrm{ka}$ ) (Bonhommet \& BABKINE 1967). Since then numerous magnetic excursions in sediments and vulcanites, whose existence and chronostratigraphic age determination are not always beyond doubt, have been described worldwide. The various authors primarily disagree concerning the assessment of the relevance of data taken from drill cores as well as the importance of independent geochronologic datings of the examined rocks (LAJ \& ChAnNel 2007). According to Lund et al. (1998) a total of 15 magnetic excursions can be observed in ODP cores within the Brunhes-Chron. According to LANGEREIS et al. (1997) 12 excursions are to be considered, 6 of which are referred to as well dated, globally observed excursions. According to SINGER et al. (2008), all excursions which have been dated radiometrically via the Ar-dating of vulcanites or astrochronological via O-isotopes in the sediments need to be considered. In contrast, LAJ \& CHANNEL (2007) consider only those 7 excursions for which worldwide proof and precise dating are available: Mono Lake (33 ka), Laschamp (40 ka), Blake (120 ka), Iceland Basin (188 ka), Pringle Falls (211 ka), Big Lost (560-580 ka) and Stage 17 (670 ka).

Above the Older Deckenschotter between 11.0 and $12.0 \mathrm{~m}$ 
$\delta^{18} \mathrm{O}$ stack $(\%)$

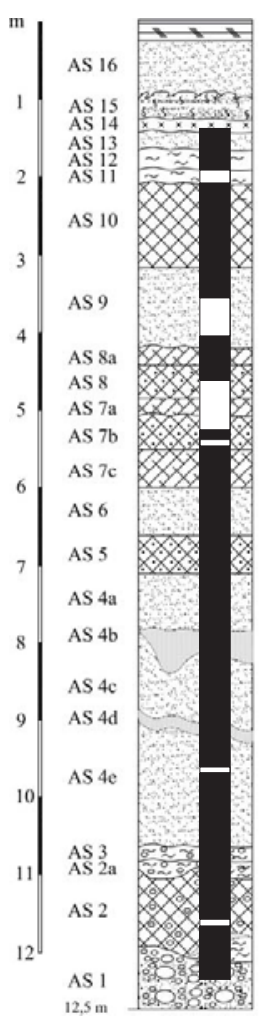

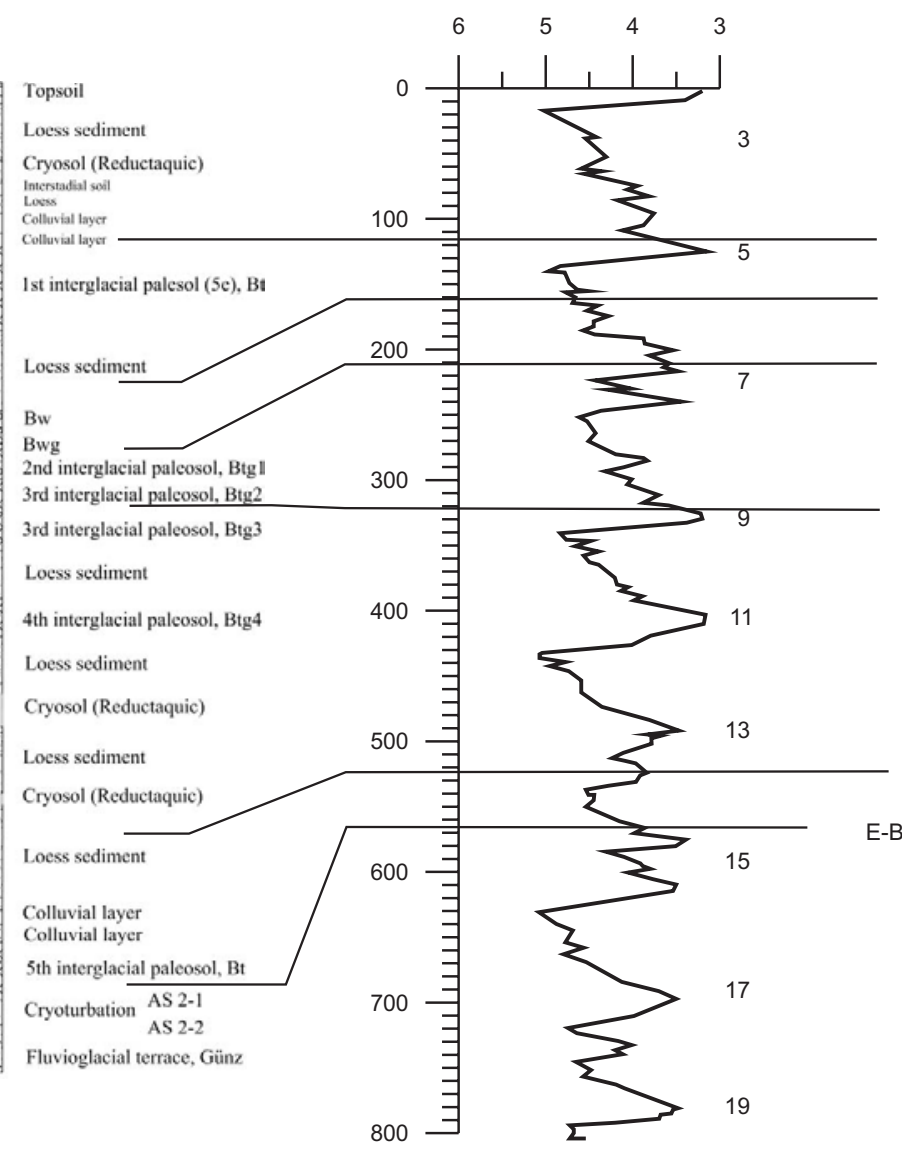

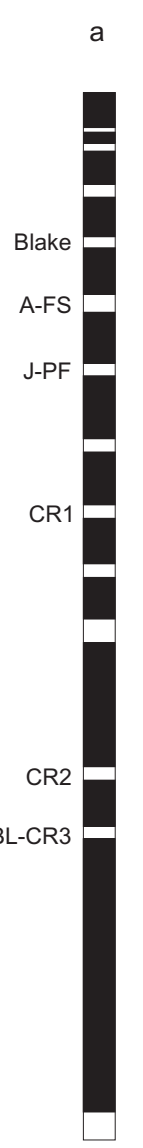

GITS

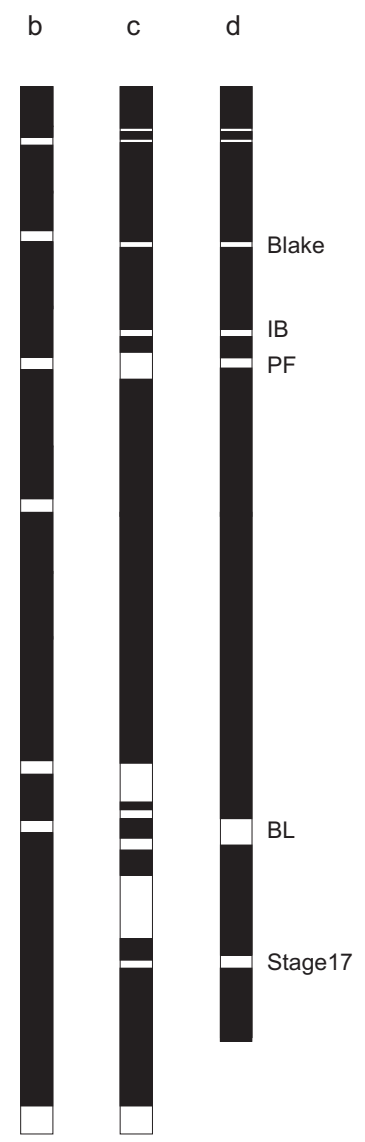

Age (ka)

Figure 3: Tentative correlation of magnetic parameters in the profile Wels-Aschet to chronostratigraphic reference scales. Oxygen isotopes after LISIECKI $\mathcal{\sigma}$ RAYMO (2005) and Geomagnetic Instability Time Scale (GITS; (a) and (b) after LANGEREIS et al. (1997), (c) after SINGER et al. (2008), (d) after LAJ \& CHANNEL (2007). Excursions (reversals) named after localities: Albuquerque (A), Fram Strait (FS), Iceland Basin (IB), Pringle Falls (PF), Calabrian Ridge (CR), Emperor (E), Big Lost (BL). Palaeopedologic profile after TERHORST et. al. (2012).

Abb. 3: Vergleich der magnetischen Parameter im Profil Wels-Aschet mit chronostratigraphischen Referenzdaten: Sauerstoffisotopen nach LISIECKI \& RAYMo (2005) und Geomagnetic Instability Time Scale (GITS; (a) und (b) nach LANGEREIS et al. (1997), (c) nach SINGER et al. (2008), (d) nach LAJ ¿ CHANNEL (2007). Bezeichnung der Exkursionen bzw. Umpolungen nach Fundorten: Albuquerque (A), Fram Strait (FS), Iceland Basin (IB), Pringle Falls (PF), Calabrian Ridge (CR), Emperor (E), Big Lost (BL). Paläopedologisches Profil aus TERHORST et. al. (2012).

of the profile a palaeosol (AS 2) has developed, which represents at least one interglacial period and, at its lowest section at $11.6 \mathrm{~m}$ in the profile, contains a magnetic excursion. The pedogentic phase might be assigned to MIS15, towards whose end the geomagnetic excursion E-BL-CR3 (Emperor - Big Lost - Calabrian Ridge 3; 570-560 ka) occurs. Above the palaeosol, colluvial, gravel bearing layers were deposited (AS 3, AS 2a). The superjacent thick loess loam (AS 4) contains a further magnetic excursion in the section under a the Cryosol AS $4 \mathrm{~d}$ at $9.5 \mathrm{~m}$ in the profile, for whose geological age two models need to be discussed. If the excursion is correlated with Calabrian Ridge 2 (CR2; 525-515 ka according to LANGEREIS et al. (1997)) or West Eifel 5 (528+-16ka according to SINGER et al. (2008)) during MIS14, it ensures that the loess sedimentation (AS 4 and AS 5) encompasses a total of two glacial periods, MIS14 and MIS12, and that an erosional discordance in AS 4 removed the soil corresponding to MIS13. The alternative model for this profile section would be that the more strongly weathered palaeosol AS 2 represents two soil formation phases (MIS13 and MIS15) and that scarcely any sediments from the glacial period MIS14 have been pre- served or they have been completely overprinted by the subsequent pedogenesis. This would mean that the whole loess loam of the layers AS 4a-e would have to be assigned to just one glacial period (MIS12).

In the loess loam AS 4a a palaeosol (AS 5) developed, which could be assigned to MIS11. The subsequent sedimentation phase in MIS10 encompasses the unsegmented loess loam (AS 6) at 6.6 to $6.0 \mathrm{~m}$ in the profile and the palaeosol (AS 7b-AS 7c), which developed from it in MIS9, in whose uppermost section at $5,4 \mathrm{~m}$ in the profile a magnetic excursion occurs which correlates with CR1 (Calabrian Ridge 1; 325-315 ka). These horizons can easily be distinguished from the superjacent soil horizon AS 7a due to a significant erosional discordance and a change in grain size (TERHORST 2007, Terhorst et al. 2011).

The loess sediments from MIS8 were completely overprinted during the subsequent soil formation phase in MIS7, so that only one segmented pedocomplex (AS 7a-AS 8a) has been preserved at 5.0 to $4.2 \mathrm{~m}$ in the profile. In the lower part of this profile section, in addition to the palaeomagnetic information on the soil formation phase during MIS7 with the 
excursion J-PF (Jamaica - Pringle Falls; 215-205 ka), some remains of the remanent magnetisation of the original loess sediment have been preserved in a highly coercive magnetic phase, which also show vector directions deviating from the North direction.

This is followed above by a further loess loam (AS 9), which was deposited during MIS6 and contains a magnetic excursion at $4.0 \mathrm{~m}$ to $3.5 \mathrm{~m}$ in the profile which can be correlated with the A-FS excursion (Albuquerque - Fram Strait; 165-155 ka). The uppermost interglacial soil in the Aschet profile (AS 10) can be assigned to Eem (MIS5e) due to its palaeopedologic characteristics as well as by superimposed sediments of Würmian age. Due to datings at the Wels-Aschet site (Preusser \& Fiebig 2011) and in comparable profiles (TERHORst et al. 2002), an Early Würmian age can be presumed for the magnetic excursion in the colluvial layer AS 11 at $2.0 \mathrm{~m}$ in the profile. The formation of the colluvial layer AS 11 is linked to the beginning decline in climate during the close of Eem, which is why at this point, the colluvial layer correlates chronostratigraphically with the occurrence of the Blake excursion (120-110 ka).

The above-discussed stratigraphic findings are in contrast to the assumption of Preusser \& FIEBIG (2009), who discuss much younger ages on the base of luminescence dating (IRSL). However, in this study, ages $>200 \mathrm{ka}$ do not significantly increase in the older sediments (c.f. PREUSSER \& FIEBIG, 2009). Recently, methodological studies were able to extend the range of the luminescence method to $300 \mathrm{ka}$ using a new post-IR IRSL protocol $\left(290^{\circ} \mathrm{C}\right)$ (THIEL et al. 2010), an approach not yet applied to the sequence of Wels-Aschet.

\section{Conclusion}

The confirmation of Middle Pleistocene magnetic excursions accompanied by palaeopedologic-pedostratigraphic analyses are important implements for the development of a chronostratigraphic framework for the studied area as well as for the stratigraphical framework of Europe. For this reason, we executed a detailed magnetostratigraphic study of the plot of the former brickyard Würzburger in Aschet.

In general, for loess/palaesol sequences, there is a methodological dependant wide gap in absolute age datings between the Matuyama/Brunhes boundary and MIS 6 in Pleistocene periglacial and glacial sediments (see discussion in Terhorst et al. 2011). Chinese loess sequences record five distinct palaeosols ( $\mathrm{S} 1$ to $\mathrm{S} 5$ ) as well as three weak soils (S6 to S8) on top of the MBB and according to GENDLER et al. (2006), five to six pedocomplexes superimpose the MBB in the western Black Sea loess area. MARKovic et al. (2011) suppose seven interglacial soils for Northern Serbia and for the Russian plane, five to six interglacial soils are present in the Brunhes-Subchron including the transition close to the Matuyama/Brunhes boundary (VELICHKo 1990).

The loess deposits of the middle and lower Danube basin in southeastern Europe comprise the most comprehensive terrestrial records of the Pleistocene environmental dynamics (Fitzsimmons et al. 2012). MARKovic et al. (2009) proposed a stratigraphic model for the Middle and Late Pleistocene based on magnetic susceptibility records from Loess sequences in the Vojvodina region (Serbia) that revealed a continuous record of paleoclimatic variations for the last five glacial/interglacial cycles at least. BugGLE et al. (2009) compared susceptibility records from pedocomplexes at Serbian, Romanian and Ukrainian loess/paleosol sections with susceptibility data of the Chinese Loess Plateau and with the oxygen isotope record of ODP 677 and related the oldest pedocomplex in their study area to Marine Isotope Stage (MIS)17.

According to our interpretation, the oldest pedocomplex in the profile Wels-Aschet (AS2) might be assigned to MIS 15 and the thick package of AS4 represents very strong cooling in the Mindel glaziation with the most extensive glaciers in this area during the MIS 12. The Older Deckenschotter terrace apparently formed during the cold phase of MIS 16 (VAN Husen \& REITNER 2011).

The correlation of magnetic parameters presented here (Figure 3) is based on the interpretation of sedimentation and soil formation phases on the basis of the palaeopedologic profile (Terhorst 2007, Terhorst et al. 2012). The magnetic parameters show a series of sections with intense magnetite formation in the soil, which can be assigned to the relatively warm climate of interglacial periods. In some sections of the profile the trend of the magnetic susceptibility shows a notable consistence with the oxygen isotope curve. Indications of short-term magnetic excursions can be observed in the section of the palaeosols as well as in the loess sediments. Due to sedimentologic considerations, the excursions observed in the Wels-Aschet profile are equated with the excursions Blake (120-110 ka), A-FS (Albuquerque - Fram Strait; 165-155 ka), J-PF (Jamaica - Pringle Falls; 215$205 \mathrm{ka}$ ), CR1 (Calabrian Ridge 1; 325-315 ka) and E-BL-CR3 (Emperor - Big Lost - Calabrian Ridge 3; 570-560 ka) of the geomagnetic reference time scales. For the excursion in the loess complex (AS4e), depending on which reference time scale is used, either CR2 (Calabrian Ridge 2; 525-515 ka), West Eifel 5 (528+-16ka) or a much younger age are up for discussion. The Brunhes-Matuyama Boundary (776 ka) was never reached.

\section{Acknowlegdements}

The palaeomagnetic investigation was performed on initiative of Prof. Dr. Dirk van Husen with financial support of the Austrian Academy of Sciences. We would like to thank Karl Stingl and Jürgen Reitner for their support during fieldwork and two anonymous reviewers for their valuable scientific and editorial support.

\section{References}

Buggle, B., Hambach, U., Glaser, B., Gerasimenko, N., Marković, S. Glaser, I., ZöLler, L. (2009): Stratigraphy, and spatial and temporal paleoclimatic trends in Southeastern/Eastern European loess-paleosol sequences. - Quaternary International, 196 (1-2): 86-106.

Bonhommet, N. \& BABKine, J. (1967): Sur la presence d'aimentation inverse dans la Chaine Des Puys. - Comptes Rendus Hebdomadaires des Seances de l'Academie des Sciences, Series B, 264: 92-94.

Chen, T., Xu, H., Xie, Q., Chen, J., Ji, J. \& Lu, H. (2005): Characteristics and genesis of maghemite in Chinese loess and paleosols: Mechansim for magnetic susceptibility enhancement in palaeosols. - Earth \& Planetary Science Letters, 240: 790-820.

DeKKeRs, M.J. (1997): Environmental magnetism: an introduction. - Geologie en Mijnbouw, 76: 163-182, Utrecht.

Evans, M.E. \& Heller, F. (1994): Magnetic enhancement and paleoclimate study of a loess/paleosol couplet across the Loess Plateau of China. - 
Geophysical Journal International, 117: 257-264.

Evans, M.E. \& Heller, F. (2003): Environmental magnetism - principles and applications of Enviromagnetics. - Amsterdam (Academic press).

Fink, J., Fischer, H., Klaus, W., Koci, A., Kohl, H., KuKla, J., LozeK, V., PIfFL, L. \& RABEDER, G. (1976): Exkursion durch den österreichischen Teil des Nördlichen Alpenvorlandes und den Donauraum zwischen Krems und Wiener Pforte. - Mitteilungen der Kommission für Quartärforschung, 1: $31 \mathrm{~S}$, Wien.

Fitzsimmons, K., Marković, S., Hambach, U. (2012): Pleistocene environmental dynamics recorded in the loess of the middle and lower Danube basin. - Quaternary Science Reviews, 41: 104-118.

Gendler, T.S., Shcherbakov, V.P., Dekkers, M.J., Gapeev, A.K., Gribov, S.K. \& MCCLELLAND, E. (2005): The lepidocrocite-maghemite-haematite rection chain- I. Acquisition of chemical remanent magnetization by maghemite, its magnetic properties and thermal stability. - Geophysical Journal International, 160: 815-832.

Heller, F. \& LiU, T.S. (1984): Magnetism of Chinese loess deposits. - Geophys. Journal of the Royal Astronomical Society, 77: 125-141, London.

Hunt, C.P., Banerjee, S.K., Han, J., Solheid, P.A., Oches, E., Sun, W. \& SolHeID, P.A. (1995): Rock-magnetic proxies of climate change in the loess-paleosol sequences of the western Loess Plateau of China. - Geophysical Journal International, 123: 232-244.

KoHL (2000): Das Eiszeitalter in Oberösterreich. Oberösterreichischer Museal-Verein, Linz, pp. 429.

Kohl, H., Krenmayr, H.G. (1997): Geologische Karte der Republik Österreich 1: 50 000, Erläuterungen zu Blatt 49 Wels. Geologische Bundesanstalt, Wien, pp. 77.

LAJ, C. \& ChAnNEL, J.E.T. (2007): Geomagnetic Excursions. - In: Treatise on Geophysics, Vol. 5. Elsevier.

Langereis, C.G., Dekkers, M.J., De Lange, G.J., Paterne, M. \& Van SANTVOoRT, P.J.M. (1997): Magnetostratigraphy and astronomical calibration of the last 1.1 Myr from a Central Mediterranean piston core and dating of short events in the Brunhes. - Geophysical Journal International, 129: 75-94.

Larrasoana, J.C., Roberts, A.P., Rohling, E.J., Winklhofer, M. \& WeHAUSEN, R. (2003): Three million years of monsoon variability over the northern Sahara. - Climate Dynamics, 21: 689-698.

Lisiecki, L.E., RAYMo, M.E. (2005): A Pliocene-Pleistocene stack of 57 globally distributed benthic d180 records. - Palaeoceanography, 20: 1-17.

Lund, S.P., Acton, G., Hastedt, M., Okada, M., Williams, T. (1998): Geomagnetic field excursions occurred often during the last million years. - EOS, 79, 14: 178-179.

MAHeR, B. (1998): Magnetic properties of modern soils and Quaternary loessic paleosols: paleoclimatic implications. - Palaeogeography, Palaeoclimatology, Palaeoecology, 137: 25-54.

Marković, S., Hambach, U., Catto, N., Jovanović, M., Buggle, B., MachAlett, B., Zöller, L., Glaser, B., Frechen, M. (2009): Middle and Late Pleistocene loess sequences at Batajnica, Vojvodina, Serbia. - Quaternary International, 198 (1-2): 255-266.

Markovic, S.B., Hambach, U., Stevens, T., Kukla, G.J., Heller, F., McCoy, W.D., Oches, E.A., Buggle, B., Zöller, L. (2011): The last million years recorded at the Stari Slankamen (Northern Serbia) loess-palaeo- sol sequence: revised chronostratigraphy and long-term environmental trends. - Quaternary Science Reviews, 30, 1142-1154.

Penck, A., Brückner, E. (1909): Die Alpen im Eiszeitalter, Vol. 1. - Tauchnitz, Leipzig, pp. 393.

Preusser, F. \& Fiebig, M. (2009): European Middle Pleistocene loess chronostratigraphy: Some considerations based on evidence from the Wels site, Austria. - Quaternary International, 198, 37-45.

Preusser, F. \& Fiebig, M. (2011): Chronologische Einordnung des Lössprofils Wels auf der Basis von Lumineszenzdatierungen. - Mitteilungen der Kommission für Quartärforschung, 19: 63-70, Wien.

Scholger, R. \& Terhorst, B. (2011): Paläomagnetische Untersuchungen der pleistozänen Löss-Paläobodensequenz im Profil Wels-Aschet. - Mitteilungen der Kommission für Quartärforschung, 19: 47-61, Wien.

Singer, B.S., Hoffman, K.A., Schnepp, E., Guillou, H. (2008): Multiple Brunhes Chron excursions recorded in the West Eifel (Germany) volcanics: Support for long-held mantle control over the non-axial dipole field. - Physics of the Earth \& Planetary Interiors, 169: 28-40.

Stremme, H., Zöller, L., Krause, W. (1991): Bodenstratigraphie und Thermolumineszenz-Datierungen für das Mittel- und Jungpleistozän des Alpenvorlandes. - Sonderverhandlungen des Geologischen Instituts Univ. Köln, 82: 301-315 (Festschrift K. Brunnacker).

Terhorst, B. (2007): Korrelation von mittelpleistozänen Löß-/Paläobodensequenzen in Oberösterreich mit einer marinen Sauerstoffisotopenkurve. - E \& G, Quaternary Science Journal, 56/3: 172-185.

Terhorst, B., Frechen, M. \& Reitner, J. (2002): Chronostratigraphische Ergebnisse aus Lößprofilen der Inn- und Traun-Hochterrassen in Oberösterreich. - Zeitschrift für Geomorphologie, Suppl.-Bd. 127: 213-232.

Terhorst, B., Ottner, F. \& Holawe, F. (2011): Pedostratigraphische, sedimentologische, mineralogische und statistische Untersuchungen an den Deckschichten des Profils Wels/Aschet (Oberösterreich). - Mitteilungen der Kommission für Quartärforschung, 19: 13-35, Wien.

Terhorst, B., Ottner, F. \& Wriessnig, K. (2012): Weathering intensity and pedostratigraphy of the Middle to Upper Pleistocene loess/paleosol sequence of Wels-Aschet (Upper Austria). - Quaternary International, 265: $142-154$.

Thouveny, N., De Beaulieu, J.L., Bonifay, E., Creer, K.M., Guiot, J., Icole, M., Johnsen, S., Jouzel, J., Reille, M., Williams, T. \& Williamson, D. (1994): Climate variations in Europe over the past $140 \mathrm{kyr}$ deduced from rock magnetism. - Nature, 371: 503-506.

VAN HusEn, D. (2000): Geological processes during the Quaternary. - Mitteilungen der Österreichischen Geologischen Gesellschaft, 92: 135-156, Wien.

VAn Husen, D., Reitner, J. (2011): Klimagesteuerte Terrassen- und Lössbildung auf der Traun-Enns-Platte und ihre zeitliche Stellung (Das Profil Wels-Aschet).- Mitteilungen der Kommission für Quartärforschung, 19: 1-12, Wien.

Velichko, A.A. (1990): Loess-Paleosol formation on the Russian Plain.Quaternary International, 7-8: 103-114.

Verosub, K.L. \& Roberts, A.P. (1995): Environmental magnetism: Past present, and future. - Journal of Geophysical Research, 100: 2175-2192, Washington. 